\title{
THE AMERICAN HISTORIGAL ASSOGIATION
}

\author{
Founded in $1884 \quad$ Chartered by Congress in 1889
}

Membership: Persons interested in historical studies, whether professionally or otherwise, are invited to membership. Present membership ca. 6,50o.

MeEtings: An annual meeting with a three-day program is held in the last days of each year. Election of officers is by ballot of the membership.

The Association maintains close relations with the state and local historical societies through conferences at the annual meetings. The Pacific Coast Branch holds meetings in December on the Pacific Coast and publishes the Pacific Historical Review.

Publications: In addition to the Annual Report, the Association publishes from time to time out of special funds important documentary collections in American political and legal history. Its official organ is the American Historical Review, published quarterly and sent to all members. It appoints a proportion of the members of the board of editors of Social Education, a journal on the social studies for secondary-school teachers.

PrIzes: The Albert $J$. Beveridge Award, given annually for the best manuscript in the history of the Western Hemisphere, has a cash value of $\$ 1,000$ and assurance of publication. Address inquiries to Professor John Tate Lanning, Department of History, Duke University, Durham, N.C.

The Watumull Prize of $\$ 500$, awarded biennially for a work on the history of India originally published in the United States.

The George Louis Beer Prize of about $\$ 200$, awarded annually for a work upon any phase of European international history since 1895 .

The John H. Dunning Prize of about $\$ 140$, awarded in the evennumbered years for a monograph on any subject relating to American history.

The Herbert B. Adams Prize of $\$ 200$, awarded in the even-numbered years for a work in the field of European history.

The Robert Livingston Schuyler Prize of $\$ 100$ awarded every five years for the best work in modern British, British imperial and Commonwealth history.

Dues: There is no initiation fee. Annual dues are $\$ 7.5^{\circ}$, students $\$ 4.00$. Life membership is $\$ 150$. All members receive the American Historical Review and the program of the annual meeting.

Correspondence: Inquiries should be addressed to Boyd C. Shafer, Executive Secretary.

The American Historical Association $4^{\text {oo }}$ A Street, S.E.

Washington 3, D.C. 